\title{
Impact of Non-Development Expenditure on Economic Development of Pakistan
}

\author{
Mohammad Salih Memon \\ Assistant Professor Department of Business Administration \\ Shah Abdul Latif University Khairpur, Sindh, Pakistan \\ saleh.memon@salu.edu.pk \\ Mohammad Ali Pasha Panhwar \\ Lecturer, Department of Economics \\ University of Sindh, Jamshoro, Sindh, Pakistan \\ ParkashLalTalreja \\ Assistant Professor, Department of Business Administration \\ Shilarpur Campus, Shah Abdul Latif University Khairpur, Sindh, Pakistan
}

\begin{abstract}
The purpose of this study was to identify the relationship between the non-development expenditure and 6 independent variables of economic development for that reason data was collected from the ministry of finance government of Pakistan and State Bank of Pakistan for above said variables for the period of 2000-01 to 2009-10 and linear regression was applied to identify the relationship and concluded that overall model is fit means independent variables in the equation is rightly predicting the dependent variable (non-development expenditure), but the strength of relationship is somehow high and positive of independent variables Health \& Nutrition expenditure with the non-development expenditure, and unemployment rate and exports according to the data and results are negatively related with the non-development expenditure, which means exports must be increased to reduce the non-development expenditure.
\end{abstract}

\section{Council for Innovative Research}

Peer Review Research Publishing System

Journal: International Journal of Management \& Information Technology

Vol. 10 No. 2

editorsijmit@gmail.com

www.ijmit.com/ois 


\section{Introduction}

In the light of the problem researchers analyzed and present a frame work for the use of fiscal (budget) policy and monetary policy as well to improve income distribution in the country and moving towards economic development.

Non-Development Expenditure: on revenue account non-development expenditure is categories in two classes, first the general service and second is the grants-in-aid to state and union territories and also to the other countries. The general services comprises of fiscal services, interest payments, administrative services, and defense services. And the topmost two components of non-development expenditures on revenue account are the defense service, and interest payments on the public debt. The elements of non-development expenditure on the capital account is, the loans and advances to the province and local governments, second, the advances to foreign countries.

\section{Economic Development Variables}

Un-Employment Rate: the percentage of total labor force that is un-employed but actively seeking employment and willingness to work. A global economic turmoil has been the reason of unemployment in the globe plus inside Pakistan 2.93 million of labor force is unwaged, it may be the mismatch in the job and skill of labor force and most of the temporary nature of jobs creates the problematic situation.

Health \& Nutrition: health is the main part of human well-being and had lots of economic benefits. Pakistan is one amongst the 115 countries in the world which recognizes the legal right of health facility. In Pakistan, the health status of the total population at large scale has improved considerably, but as far as international comparison is concerned, position is mixed, but in general there are the improvements.

Exports: to send or shipped the commodities abroad, especially for the purpose of sale. The target of Pakistan was $\$$ 24.8 billion or simply said that $4 \%$ higher than last year for $2012-13$.

Imports: to bring goods and materials in from other sources, especially from other countries for the trade. Import growth of Pakistan become slow and showing negative growth of $1.02 \%$ during staring ten months of current fiscal year.

CPI: $\mathrm{CPI}$ is a gauge of subjective standard of prices of case of supplies or services demanded by consumers for example: transportation, food and etc. The CPI can easily be calculated by collecting price changes for the items of specific group and averaging them, but the importance of the goods create the weight accordingly.CPI is most commonly used statistical method for knowing the times of inflation or deflation. It is only because of high increase of CPI in short period is known as era of price increase, plus high cut in CPI into squat era is usually known as periods of deflation.

Investments: any asset or good purchased with the expectation that it will yield income. In the economic sense purchase of goods for use in coming future for creation of wealth is known as investment. And investment is a monetary asset purchased for the purpose that it will provide income and gain at the time of sale; is about the financial sense. Investment can proceed through two different ways; (direct investment and indirect investment).Investment got the main role in determining the economic growth of any country, and productive capacity can only be enhanced by the investment and will lead to the employment opportunities. Investment depends upon the number of other factors that is why it is the reason of major fluctuations in GDP.

\section{Literature Review}

Many theories are for the magnitude of public liability as well as their consequence on economic growth. The main concern is that when governments are facing the shortage be likely to describe on capital that private division could have worn to collect private corporeal money. If governments are involving their self in any expenditure which is less dynamic, as compare to private zone, than we are facing overall reduction in economic growth (Lin, 2000) and others who are of the opinion that public liability do not essentially decrease the economic growth.

Research of (Levine \& Renelt, 1992) pointed out that one from 3 unadventurous variables of fiscal plan on its own sufficiently detain the stance of fiscal plan of a few given economies.

Most of the researchers demonstrated that no any sole indicator sufficiently represents the stance of fiscal plan; on the other hand recommended by (Fu, Taylor, \& Yucel, 2003) pair wise combination of the fiscal pointers can better exemplify a sequence of actions related to fiscal plan.

(Abdullah, 2000) scrutinized the association among government spending as well as economic growth, concluded that magnitude of government is of more importance in decisive performance of economy, furthermore governments should not just hearten the private part to gear up the economic growth except to that boost its budgetary provisions regarding infrastructure, societal as well as economic actions.

Impact of governmental spending on economic growth was also investigated by (Gregoriou \& Ghosh, 2007) via group data, concluded that countries by means of huge government spending in terms of budgetary requirements tends to practice high economic growth but the impact diverge from country to country.

(Njikamp \& Poot, 2004) demeanor a Meta investigation of previous pragmatic studies of growth and fiscal plan moreover concluded that from the overall sample of 41 studies $29 \%$ designate negative association among fiscal plan and economic growth, $17 \%$ positive, and $54 \%$ inclusive association. 
Study of $(E k p o, 1994)$ in Nigeria was concerned with overall involvement of public spending to the growth over the 1960 1992, and concluded that support to fiscal policy led growth with the help of too many private investment resulting from government spending of infrastructure. Other researchers also analyzed the impact of government spending on economic growth in Nigeria and concluded that entirety capital spending of government, spending for recurrent and education have negative impact on economic growth, whereas spending on health, transport and communication are augmenting the economic growth.

The observations of (Omitogun \& Ayinla, 2007) regarding Keynesian school of thought cleared about an optimistic connection among investment and deficit financing on economic growth. The school of thought looks at the fiscal plan as a means of surmount disturbances inside the economy as pointed out by (Tchokote, 2001). This school suggests deficit financing as an imperative instrument for accomplishing a specific level of overall demand unswerving with the level of full employment. Whenever loaning facility is utilized for government spending, income of consumer will increase. When this capital will not be fully consumed, horde out of private investment by towering interest rates would not happen. Fiscal plan is well thought imperative capricious which may be the reason for changes in national income in developing countries, while stimulating the economic growth with the help of fiscal policy.

In conventional model a tax cut on federal level without diminution within federal spending will enhance consumption plus earning on interest due to boost in disposable personal income. The similar alteration in fiscal plan will not give the results in a few above given macroeconomic impacts. Very simple, the lessening within deficit financed federal cut in taxes will not influence macroeconomic outcomes (Saxton, 1999).

Lots of research is available for sound effects of fiscal plan on the economic growth of Pakistan are silent at its immaturity. (Shabir \& Mahmood, 1992), (Khilji \& Mahmood, 1997), and (Iqbal \& Zahid, 1998) finished that fiscal shortfall is one of the most considerable variables that affect the economic enlargement of Pakistan.

On other hand (Haq, 2003) squabble that fiscal deficit does not have any upshot on major macroeconomic gauge like: investment, inflation, and gross domestic production. The fiscal plan impacts on economic expansion can also be identified throughout broadcast mechanism; it influence economic growth with demand as well as supply sides (Khalid, Malik, \& Sattar, 2007) according to that fiscal plan is well thought-out to have a dynamic conduction mechanism, as is contains spreader policy legs for various macroeconomic variables, along with its diverse impacts on important macroeconomic variables.

Many other research studies were conducted for examining the brunt of fiscal plan variables on the growth of economy investment, consumption inflation, exchange rate, external deficit, and many other activities (Hoeppner, 2003), (Perotti, 2005), (Amanja \& Morrissey, 2005), and (Rezk, Avramovich, \& Basso, 2006).

Government expenditures, tax revenue along with budget deficit, used as fiscal plan variables and found different responses from different researchers. Only few studies were about the fiscal plan effects on explicit macroeconomic variables especially in Pakistan (Haque \& Monitel, 1991), (Ahmad \& Qayyum, 2008), \&(Khalid, Malik, \& Sattar, 2007). Also other researchers include budget deficit in analysis in addition to that it is one of the momentous variables affecting the growth of economy (Shabir \& Mahmood, 1992), (Iqbal, Z, 1995), and (Khilji \& Mahmood, 1997).

Economic development is invariant for any type of policy. Only when transitions of economies to the balanced state; can economic policies have the effect on growth rate. Starting stair toward the association among the governmental expenditure, taxes, as well as economic growth, is of the at most important to categorize government actions in a number of other categories. The most of the division is in to spending and revenue enhancement. Spending can further be divided in government expenditure, and government investment. We also need further classification in revenues so that they can be maximized.

The incomplete effects can simply be confirmed, the truth of government expenditure must be reduced with the revenue to respond complex and nonlinear relationship among government spending and growth, this is clearly highlighted in hypothetical work on endogenous expansion along with position of the government by (Barro, R J, 1990) within his sculpt he assumed that services granted by the government are of the very fruitful use in the private segment. However government spending should be completed by a relative tax on income.

Although many reasonable distortions affect the government taxation has been identified in previous literature. Imposing taxes is not only the way of increasing revenue for government to back up the revenue, but that is an instrument with which income fairness/inequality plus labor markets may be exaggerated, increasing taxes on labor will result in increase in labor charges. As (Daveri \& Tabellini, 1997) excessively increasing cost of men power will definitely leads you to increased unemployment rate as well as slows down in economic growth.

Governments are performing important and influential role in allotment of income over different representative in the economy. According to (Persson \& Tabellini, 1991) income distribution is of most importance, and income inequality is harmful to the economic growth, societies with more inequalities where conflicts of distribution are imperative, is differentiated via political decisions that permit private individuals to suitable amount of return on accretion of human plus physical capital, these people faced with inferior capital accretion rate. Indirectly fiscal policies are reducing inequality and said to be favorable economic growth, by providing generous social benefits, on other hand government may foster unemployment which leads to reduction in economic growth (Daveri \& Tabellini, 1997).

Governments have key role in providing influential frame work of clearly defined property rights, and monetary system with unwavering price. An attractive point concerned with this issue was presented by (Olson, 1982). He told that society 
enjoying political constancy for long time; mostly it is developing a powerful interest organization that in result trying to make it fewer competent economically. They will have both options:

1. Enticement to make society prosperous in which they will have to drive,

2. Advantage to reallocate income to their constituent with extra saddle as probable.

Factor in which involvement of government for meeting local point of view in the level of frankness of the economic structure. While the major concern is economic growth, concentration may be directed to the way in which junction a cross the countries is affected by openness (Puga, 1999). The meaning of buy and sell, capital flows, dissemination of products, plus progression innovations as well as migrants at the regional and international level propose that major interaction needs to be measured, in conditions of effects on growth plus technological changes.

(Romer P. M., 1986) Showed that increased growth rate is the result of amalgamation of local economies, it is also feasible that a specialty based on relative benefit in to investment within research and development actions by resource prosperous economies.

Variations of economic growth is studied by (Easterly, Kremer, Pritchett, \& Summers, 1993) they started their work with the view that much of the literature concerned with the growth defines the differences in the performance of growth by highlighting the differences on the uniqueness of the country such as saving rate, intensity of education, and different type of other policy measures. It is clearly shown in their research that there is little persistence of growth rate over time.

An important fact is that traditional trade theories emphasizes that it is increased openness, and not compulsorily exact amount of business that should direct to the equalization of income, the reference of earlier work point to an extremely healthy affiliation (Barro \& Sala-i-Martin, 1992) and concluded that stage of buy and sell may be viewed as a suitable substitute for the level of directness for the country.

Undeniably number of experimental studies is providing evidence about income junction between the countries look like an existing feature along with the countries that extensively trade each other. Although evidence is weak for the countries who increasingly open experience of higher economic growth were originated by (Kormendi \& Meguire, 1985), and (Hasnen, 1994) concluded that there is insignificant relation among the exports and economic growth.

In order to define the measurement of degree of political stability (Barro, R J, 1991) used 2 variables from bank's 1979 data set

1. Quantity of revolutions along with accomplishment per year,

2. Quantity per million populace of political associations each year

The major idea behind using these two variables is obvious. Enhancement in the chances of being put back with the enough small time periods, the political leadership is mostly diverted to carry on expropriator action until the cost can be passed over the successors.

Fiscal policy is contributing overall economic stability through three channels (Blinder \& Solow, 1974):

\section{First:}

1. Automatic decrease in government saving during downturn,

2. Increasing during upturn,

3. Cushioning shocks to national spending

Such stabilization occurs because of the tax revenue proportional to national income and expenditure, and commitment of the governments leads to the public spending and specifically designing of programs to support the spending during the downturn including unemployment benefits. The extent to which; consumption of government is low than other components of gross domestic spending.

\section{Second:}

Governments are intentionally changing public expenditure along with levy instruments to control fluctuations of business cycle.

\section{Third:}

For maximization of economic efficiency and market flexibility a system of tax transfer can be intended, thereby increasing the pliability of the economy in the face of upsets.

The mainly essential in our view is the missing of normally accepted conjectural frame work to direct the experiential research (Galor, 2005). This work would pin downward the imperative determinants of expansion being or not being the variable of fiscal policy. If that type of work is available: than we can examine the statistical implication of the hypothesized fiscal and non-fiscal determinants of growth, another issue regarding inappropriate division of some expenditure as productive and unproductive is the issue of debate in the theoretical literature of (Kneller, Bleaney, \& Gemmel, 1999).

If it is factual, than the effect of alteration in expenditure growth will be unimportant, still we do not have more observation, for that we cannot examine this case, for example: the quadratic term in the regression (Benos, 2005), (Karras, G, 1996), 
and (Kalaitzidakis, Mamuneas, Savvidis, \& Stengos, 2001). Finally the horizon of three years is not enough to capture the long-run expansion effects of public expenditure on formation of human capital (Kneller, Bleaney, \& Gemmel, 1999).

Figure 3.8 Unemployment Shocks
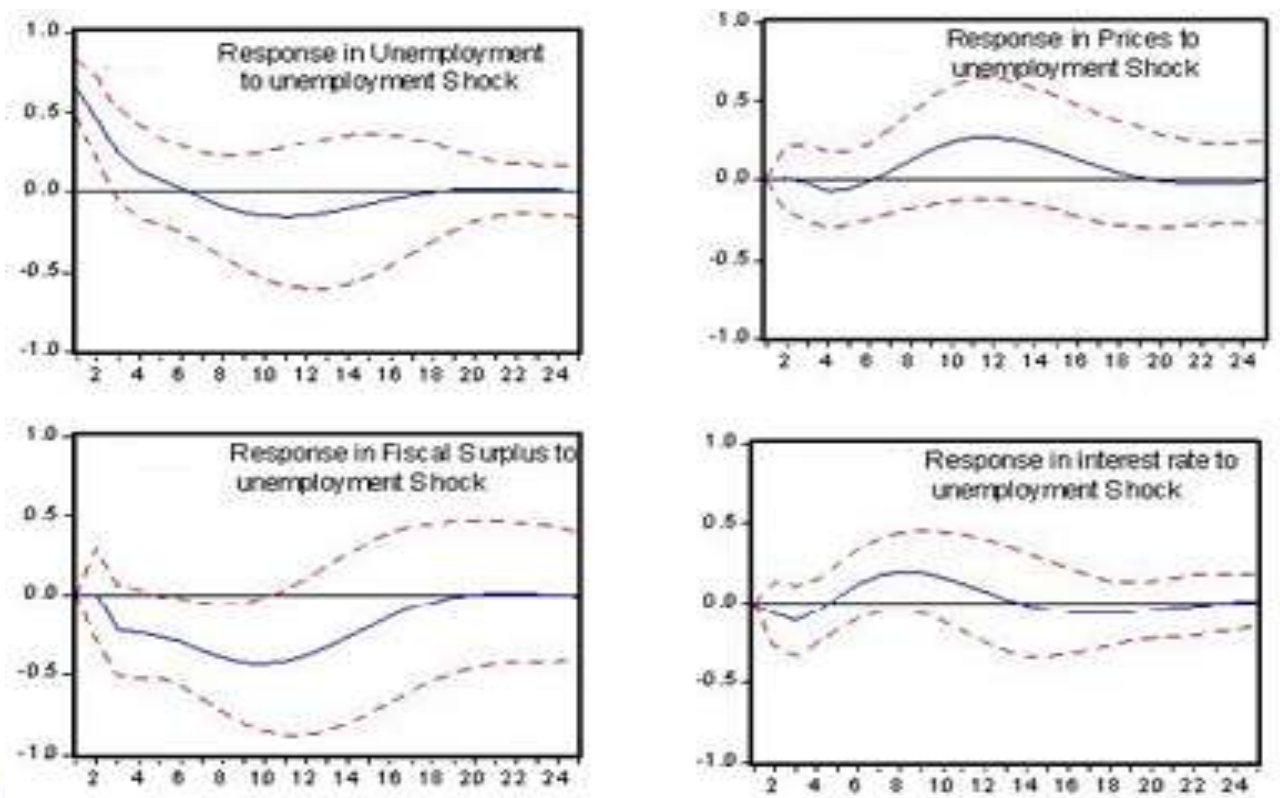

Finally due to long period of time it was finished that nearby feeble or diminutive dexterity between policy makers.

Fiscal plus monetary policy is the tools, by which an economic system can be governed or regulated by the centralized banking authority, fiscal policy is concerned by the levy and expenditure resolution of the authorities and monetary policies are invented by monetary establishment and concerned with the quantity of money circulated plus interest rate existing within the economy. The intention of fiscal plan is to preserve the lofty employment stage in the economy and monetary plan is linked with the creation of money along with altitude of interest rate by keeping in view the intensity of inflation within the economy (Lewis \& Leith, 2000). 


\section{Methodology}

At first instance data was collected from the ministry of finance, government of Pakistan and State bank of Pakistan for above mentioned variables of Non-development expenditure and six variables of economic development of Pakistan year wise and linear regression was applied to

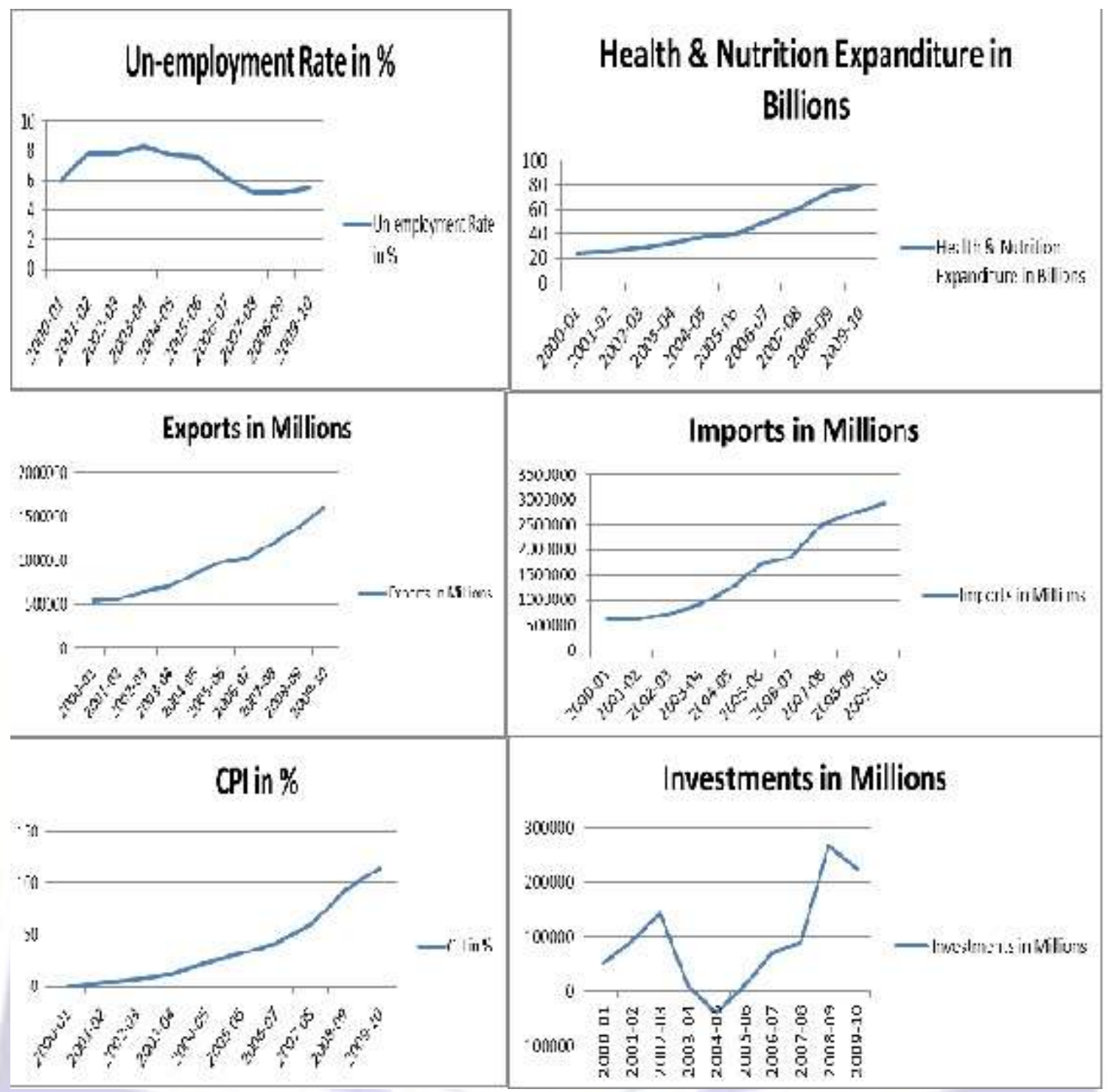

Uses the non-development expenditure as dependent variable and all six development variable as a independent variables, and accordingly diagnostic test was applied: is given below

$\mathrm{NDE}=\alpha+\mathrm{UER} \beta 1+\mathrm{H} \beta 2+\operatorname{Ex} \beta 3+\operatorname{Im} \beta 4+\mathrm{CPI} \beta 5+\operatorname{In} \beta 6+\mu$

\section{Results and Discussions}

\begin{tabular}{|c|c|c|c|c|c|c|c|}
\hline \multirow[b]{4}{*}{ Mode] } & \multirow[b]{4}{*}{$F$} & \multirow{4}{*}{$\begin{array}{c}\mathrm{R} \\
\text { Square }\end{array}$} & \multirow{3}{*}{$\begin{array}{c}\text { Adpisted } \\
\mathrm{R}\end{array}$} & \multicolumn{4}{|c|}{ Chamestatiotio } \\
\hline & & & & Stit. Error & $\mathrm{F}$ & & $\mathrm{Siz} F$ \\
\hline & & & & & Square & $\mathrm{F}$ & Charge \\
\hline & & & Square & Estimate & Chirge & Charge & \\
\hline $\bar{l}$ & 996 & 993 & 978 & 904630 & 93 & 6730 & .019 \\
\hline
\end{tabular}


Model of Non-Development Expenditure (Dependent variable), and UER, H, Ex, Im, CPI, and Investments is fit and properly applied as stated by the value of R-Square from the equation; furthermore it is significant at the .003 levels.

\begin{tabular}{|c|c|c|c|c|c|}
\hline \multirow[t]{2}{*}{ Model } & \multicolumn{2}{|c|}{$\begin{array}{l}\text { Unstandardized } \\
\text { Coefficients }\end{array}$} & $\begin{array}{l}\text { Standardized } \\
\text { Coefficients }\end{array}$ & \multirow[b]{2}{*}{$t$} & \multirow[b]{2}{*}{ Siz. } \\
\hline & B & Std. Errox & Beta & & \\
\hline (Constart) & 181416.966 & 697713065 & & 264 & .809 \\
\hline Unerrqloyment Rate & -25813.350 & 56573.504 & -.052 & -.456 & .679 \\
\hline Health \& Hutrition & 17403908 & 16537.045 & .568 & 1.052 & .370 \\
\hline Exports & -.225 & 1.453 & -.134 & -.155 & .87 \\
\hline Imports & .256 & 334 & .376 & .768 & .499 \\
\hline Consumer Frice Index & 1413.325 & 12171.577 & .001 & .116 & .915 \\
\hline Wet Investments & .541 & .723 & .086 & .748 & .509 \\
\hline
\end{tabular}

While looking at the results explanatory power of independent variables is not up to the mark except Health \&Nutrition Expenditure, and somehow Imports.

\section{Conclusions}

Overall model is fit means independent variables in the equation is rightly predicting the dependent variable (nondevelopment expenditure), but the strength of relationship is somehow high and positive of independent variables Health \& Nutrition expenditure with the non-development expenditure, and unemployment rate and exports according to the data and results are negatively related with the non-development expenditure, which means exports must be increased to reduce the non-development expenditure.

\section{References}

1. Abdullah, H. A. (2000). The Relationship Between Government Expanditure and Economic Growth in Saudi Arabia. Journal of Administrative Sciences 12(2) , 173-191.

2. Ahmad, I., \& Qayyum, A. (2008). Effect of Government Spending and Macroeconomic Uncertanity on private investment in Services Sector: Evidence from Pakistan. European Journal of Economics, Finance and Administrative Sciences 11, 1450-2275.

3. Amanja, D. M., \& Morrissey, O. (2005). Fiscal Policy and Economic Growth in Kenya. CREDIT Research Paper No. 05/06

4. Barro, R J. (1991). Economic Growth in a Cross Section of Countries. Quarterly Journal of Economics, vol 104 , 407443.

5. Barro, R J. (1990). Government Spending in a Simple Model of Endogenous Growth. Journal of Political Economy vol $98,103-125$.

6. Barro, R. J., \& Sala-i-Martin, X. (1992). Convergence. Journal of Political Economy 100(2) , 223-251.

7. Benos, N. (2005). Fiscal Policy and Economic Growth: Empirical Evidence from OECD Countries. University of Cyprus Department of Economics Working Paper 2005-01, 1-51.

8. Blinder, A., \& Solow, R. (1974). Analytical Foundations of Fiscal Policy in the Economics of Public Finance. Brooking Institutions Washingto DC .

9. Daveri, F., \& Tabellini, G. (1997). Unemployment Growth and Taxation in Industrial Countries. Part of World Bank Research Project on Growth and Labor Markets .

10. Easterly, W., Kremer, M., Pritchett, L., \& Summers, L. H. (1993). Good Policy or Good Luck? Country Growth Performance and Temporary Shocks. Journal of Monetary Economics vol.32 , 459-483.

11. Ekpo, A. (1994). Public Expenditure and Economic Growth in Nigeria 1960-1992. Final Report, Nairobi: AERC .

12. Fu, D., Taylor, L. L., \& Yucel, M. K. (2003). Fiscal Policy and Growth, Research Department Working Paper 0301. Federal Reserve Bank of Dollas .

13. Galor, O. (2005). From Stagnation to Growth: Unified Growth Theory, in Philippe Aghion and Stefen Durlauf . Hand Book of Economic Growth, Amsterdam North Holland .

14. Gregoriou, A., \& Ghosh, S. (2007). The Impact of Government Expanditure on Growth: Emprical Evidence from Hetrogeneous Panel. Retrieved from http://www.brunel.ac.uk/9379/efwps/0701.pdf. 
15. Haq, A. T. (2003). Fiscal Strategy For Growth and Employment in Pakistan: An Alternative Consideration. International Labor Office Islamabad (Employment Paper 56).

16. Haque, N. U., \& Monitel, P. (1991). The Macroeconomics of Public Sector Deficite: The Case of Pakistan. The World Bank Policy Research Working Paper Series673.

17. Hasnen, P. (1994). Investment Data and Emprical Relationship Between Exporters, Government, and Economic Growth. Applied Economic Letters vol 1, 107-110.

18. Hoeppner, F. (2003). Business Cycle Effects of Fiscal Policy: Emprical Evidence from Germany. Disertation

19. Iqbal, Z. (1995). Constraints to the Economic Drowth of Pakistan: A Three Gap Approach. The Pakistan Development Review 34:4, 1119-1133.

20. Iqbal, Z., \& Zahid, G. M. (1998). Macroeconomic Determinents of Economic Growth in Pakistan. The Pakistan Development Review 37:2, 125-148.

21. Kalaitzidakis, P., Mamuneas, T. P., Savvidis, A., \& Stengos, A. (2001). Measures of Human Capital and Non Linearities in Economic Growth. Journal of Economic Growth, 6 , 229-254.

22. Karras, G. (1996). The Optimal Government Size: Further International Evidence on the Productivity of Government Services. Economic Inquiry XXXIV , 193-203.

23. Khalid, M., Malik, W. S., \& Sattar, A. (2007). The Fiscal Reaction Function and The Transmission Mechanism for Pakistan. The Pakistan Development Review 46:4 , 435-447.

24. Khilji, N. M., \& Mahmood, A. (1997). Military Expanditures and Economic Growth in Pakistan. The Pakistan Development Review 36:4 , 435-447.

25. Kneller, R., Bleaney, M. F., \& Gemmel, N. (1999). Fiscal Policy and Growth: Evidence from OECD Countries. Journal of Public Economics, 74, 171-190.

26. Kormendi, R. C., \& Meguire, P. G. (1985). Macroeconomic Determinents of Growth. Journal of Monetary Economics, vol $16,141-163$.

27. Levine, R., \& Renelt, D. (1992). A Sensitivity Analysis of Cross-Country Growth Regressions. American Economic Review, 82(5) , 942-963.

28. Lewis, S. W., \& Leith, C. (2000). Interactions between Monetary and Fiscal Policy Rules. The Economic Journal , 110 (462), 93-108.

29. Lin, S. (2000). Government Debt and Economic Growth in a Developing Generations Model. Southern Economic Journal, 66(3) , 754-763.

30. Njikamp, P., \& Poot, J. (2004). Meta-Analysis of the Effect of Fiscal Policy on Long Run Growth. European Journal of Political Economy $20,91-124$

31. Olson, M. (1982). The Rise and Decline of Nations. Yale University Press, New Heaven and London

32. Omitogun, O., \& Ayinla, T. A. (2007). Fiscal Policy and Nigerian Economic Growth. Journal of Research in National Development, 5(2) December.

33. Perotti, R. (2005). Estimating The Effects of Fiscal Policy in OECD Countries. CEPR Discussion Paper Series No. 4842 .

34. Puga, D. (1999). The Rise and Fall of Regional Inequalities. European Economic Review 43(2) , 303-334.

35. Rezk, K., Avramovich, M. C., \& Basso, M. (2006). Dynamic Effects of Fiscal Shocks upon Diverse Macroeconomic Variables: A Structural VAR Analysis for Argentina. XLI Annual Renion of the Argentine Association of Political Economy, National University of Salta .

36. Romer, P. M. (1986). Increasing Returns and Long-run Growth . Journal of Political Economics 94(5) , $1002-1037$.

37. Saxton, J. (1999). Tax Expanditure: A Review and Analysis. Joint Economic Committee Study. http://www.house.gov/jec/fiscal/tax/expend.htm .

38. Shabir, T., \& Mahmood, A. (1992). The Effects of Foreigh Private Investment on Economic Growth in Pakistan. The Pakistan Development Review 31:4, 831-841.

39. Tchokote, J. (2001). Macroeconomics of Fiscal Deficits in Cameron. Ph. D Thesis Proposal Presented to Department of Economics University of Ibadan . 